\title{
On the cellular origin of cardiosphere-derived cells (CDCs)
}

\author{
Eduardo Marbán ${ }^{1}\left[\right.$. Ke Liao ${ }^{1}$
}

Received: 22 January 2022 / Revised: 24 January 2022 / Accepted: 25 January 2022 / Published online: 8 March 2022

(c) The Author(s), under exclusive licence to Springer-Verlag GmbH Germany 2022

Over the past 17 years, cardiosphere-derived cells (CDCs) have been developed as a therapeutic candidate for regenerative therapy $[23,30]$. These cardiac stromal cells (which are entirely distinct from discredited c-kit-positive cells [7, 36]) exhibit multilineage potential and clonogenicity [10, 30], thus qualifying as progenitors, but work primarily through indirect mechanisms $[9,14]$. At least 70 independent labs worldwide have published on CDCs (see, e.g. [1, 11, 27, 31, 32, 39]). Meanwhile, ten clinical trials, seven in the USA and three independently performed in Japan, have investigated CDCs for cell therapy. The first, an NIHfunded trial called CADUCEUS [19, 21], used intracoronary autologous CDCs in patients with mild heart failure with reduced ejection fraction (HFrEF) following myocardial infarction (MI). The Japanese trials have likewise used autologous CDCs, with a focus on hypoplastic left ventricle (LV) or dilated cardiomyopathy [31]. Subsequent clinical trials in the USA have used allogeneic CDCs, which were found to produce equivalent benefits but are more realistic as clinical products $[20,23]$. These include ALLSTAR [18] (post-MI patients with mild HFrEF; NCT01458405), DYNAMIC [6] (advanced HFrEF; NCT02293603), and HOPE-Duchenne [33] and HOPE-2 [25] (for muscular dystrophy and its associated cardiomyopathy; NCT02485938 and NCT03406780). Those trials, now completed, have verified not only are CDCs safe, but also they may have disease-modifying bioactivity in humans. Mechanistically, the prevailing concept of CDC efficacy centers on the "paracrine hypothesis", which posits transplanted cells produce salutary soluble factors [13]. Benefits of CDCs and their secreted paracrine factors include anti-fibrotic effects [34,

This comment refers to the article available at https://doi.org/10. 1007/s00395-022-00913-y

Eduardo Marbán

eduardo.marban@cshs.org

1 Cedars-Sinai Medical Center, Smidt Heart Institute, 127 South San Vicente Boulevard, AHSP A3600, Los Angeles, CA 90048, USA
35], anti-apoptotic effects on myocytes [8, 16], angiogenesis $[9,34]$, modulation of inflammatory processes and oxidative stress [3, 34], and promotion of cardiomyocyte cell cycle re-entry [22]. CDC-secreted exosomes, $\mathrm{CDC}_{\mathrm{EXO}}$ (which are a class of extracellular vesicles), mediate the major benefits of CDCs via cell-cell transfer of therapeutic payloads [2, 14, 29]. Analysis of $\mathrm{CDC}_{\mathrm{EXo}}$ payload using RNA sequencing (RNA seq) and proteomics has revealed numerous species of noncoding RNA (ncRNA) and proteins [5, 14], some of which are known to be bioactive and others which have yet to be functionally characterized.

In the beleaguered field of cardiac cell therapy, CDCs are rare in their continued viability along the clinical development pathway [24]. Despite the extensive, and growing, interest in this cell type, relatively little is known about their cellular origin. We do know that CDCs are intrinsic cardiac cells; they do not arise from hematogenous seeding [38]. CDCs are uniformly CD105 positive but, unlike fibroblasts, are low in CD90 (an antigen whose presence correlates negatively with regenerative potency [7, 12]). Moreover, genetic lineage tracing in mice has revealed that CDCs do not originate from cardiomyocytes [40]. Beyond that, however, the origin of CDCs remains mysterious. Presumably, CDCs arise from a cell type present in intact myocardial stroma, but which proliferates in primary culture during the cardiosphere formation process.

Correctly recognizing the knowledge deficit as to CDC origin, Doppler and colleagues [15] have tackled this question using contemporary cell phenotyping approaches. CDCs are compared to non-myocyte cell types (cardiac fibroblasts [CFs], smooth muscle cells [SMCs], endothelial cells [ECs], and adipose tissue derived fibroblasts [AFs]). Single cell-RNAseq was used to gauge the transcriptional similarities and differences among these various cell types. CDCs emerge as a unique cell type, distinct from any other. A striking finding, one of the most impactful in the paper, is that genes coding for the chemokine ligand CXCL6 and the cytokine IL-1 $\beta$ were highly expressed in CDCs but not in any of the comparator cell types, suggesting CXCL6 and IL-1 $\beta$ could serve as novel discriminating markers specific 
to CDCs. Additionally, mitochondrial genes were richly expressed in CDCs, but not in CFs, SMCs or ECs. Using bioinformatics approaches [37] to compare these cell populations, CDCs were found to be unique, albeit with some similarities to CFs, SMCs and ECs.

The authors further push the notion of similarity to CFs, and even go so far as to speculate that CDCs might originate from CFs. However, there is neither good evidence to support this claim, nor are the methods capable of definitively testing this claim. The major piece of evidence cited for the conjecture that CDCs arise from CFs is Fig. 3, panels D and F. Panel D shows pseudotime trajectories. Such analysis is typically undertaken not to compare diverse cell types, but rather to infer temporal gene expression changes within a single cell type studied under various conditions (e.g., as might have been done to compare old and young CDCs, or the transition from a precancerous state to a cancerous one in a given line). Here, the analysis has been pushed to situations where it was never meant to be applied. To quote from a recent review in the Journal of Immunology [26]: "The analytical approach called pseudotime analysis assumes a continuum of cellular states and aims to reveal cellular progression by inferring cellular trajectories. This type of analysis is particularly useful for studying cellular differentiation or disease progress." Here, the authors ASSUME that CDCs and CFs comprise a continuum of cellular states, forcing the analysis to reach biologically dubious conclusions. The algorithms will create trajectories no matter what they are fed; it is up to the biologists to stipulate what comparisons make sense. In Fig. 3F, Velocyto software is used to generate RNA velocity analyses. Once again here, the fundamental question seems not to adhere to the situation being analyzed. Quoting Bergen et al.[4]: "Velocyto estimates velocities under the assumptions... that (1), on the gene level, the full splicing dynamics with transcriptional induction, repression and steady-state mRNA levels are captured; and (2), on the cellular level, all genes share a common splicing rate. These assumptions are often violated, in particular when a popиlation comprises multiple heterogeneous subpopulations with different kinetics." Clearly, here the cluster analysis, and the very fact of how the cells were isolated, testify to the presence of "multiple heterogeneous subpopulations", undermining the RNA velocity analysis. Thus, it is unclear what, if anything, can be gleaned from Fig. 3D, F, but certainly it cannot be concluded that CDCs are derived from CFs. Genetic lineage analysis, which the authors did not attempt, would have been required to draw firm conclusions about cell origin.

The authors further contrast CDCs to what they call "cardiac progenitor cells" derived from human iPS cells, and found no overlap between these two cell types by cluster analysis. Once again, however, the conclusions are overstated. The "cardiac progenitor" differentiation

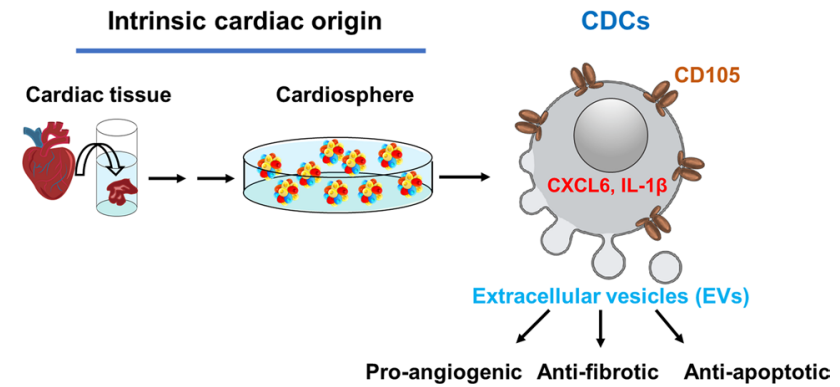

Fig. 1 Schematic diagram demonstrating molecular identity of CDCs and effects of CDC-EVs. Cardiosphere-derived cells (CDCs), a kind of cardiac stromal/progenitor cell, obtained from heart biopsy after a series of primary culture steps. They are of intrinsic cardiac origin with uniform expression of CD105 (endoglin), but are negative for the pan-hematopoietic marker (CD45). New findings from group of Doppler reveal that CXCL6 and IL1- $\beta$ are specific transcriptomic markers for CDCs. Secreted extracellular vesicles mediate the disease-modifying bioactivity of CDCs

protocol used in this paper actually produces cardiomyocyte precursors $[17,28]$. The contrast with CDCs is thus not surprising, as it is already known, from lineage tracing using MerCreMer-Z/EG transgenic mice, that CDCs do not originate from cardiomyocytes [10].

Finally, the functional testing of CDCs here, while not extensive, yielded anemic results. As aforementioned, CD90, also known as thymocyte differentiation antigen 1, is negatively associated with CDC potency: the higher the CD90 fraction, the lower the observed preclinical benefits $[7,12]$. The CDCs used here contain high proportions of CD90 + cells, rationalizing their limited efficacy.

So what can be reliably concluded from the extensive work by Doppler et al., in the context of what was already known about CDCs? As summarized in Fig. 1, CDCs are a unique cell type in terms of their antigenic (high CD105, negative for CD45) and transcriptomic profiles (high CXCL6, IL1 $\beta$ ). They are of intrinsic cardiac origin. While the present study has added evidence for the uniqueness of CDCs, we are no further along in identifying their precise cellular origin, or in vivo correlates, than we were before.

Acknowledgements Work in the Marbán laboratory is funded by $\mathrm{NIH}$, the California Institute for Regenerative Medicine, and the US Department of Defense. Prof. Marbán holds the Mark S. Siegel Family Foundation Distinguished Chair of the Cedars-Sinai Medical Center.

\section{Declarations}

Conflict of interest E. Marbán holds the Mark S. Siegel Family Distinguished Chair of the Cedars-Sinai Medical Center. E. Marbán owns founder's equity in Capricor Therapeutics. The other author report no conflicts. 


\section{References}

1. Aghila Rani KG, Kartha CC (2010) Effects of epidermal growth factor on proliferation and migration of cardiosphere-derived cells expanded from adult human heart. Growth Factors 28:157-165. https://doi.org/10.3109/08977190903512628

2. Aminzadeh MA, Rogers RG, Fournier M, Tobin RE, Guan X, Childers MK, Andres AM, Taylor DJ, Ibrahim A, Ding X, Torrente A, Goldhaber JM, Lewis M, Gottlieb RA, Victor RA, Marban E (2018) Exosome-mediated benefits of cell therapy in mouse and human models of duchenne muscular dystrophy. Stem Cell Rep 10:942-955. https://doi.org/10.1016/j.stemcr.2018.01.023

3. Aminzadeh MA, Tseliou E, Sun B, Cheng K, Malliaras K, Makkar RR, Marban E (2015) Therapeutic efficacy of cardiospherederived cells in a transgenic mouse model of non-ischaemic dilated cardiomyopathy. Eur Heart J 36:751-762. https://doi.org/ 10.1093/eurheartj/ehu196

4. Bergen V, Lange M, Peidli S, Wolf FA, Theis FJ (2020) Generalizing RNA velocity to transient cell states through dynamical modeling. Nat Biotechnol 38:1408-1414. https://doi.org/10.1038/ s41587-020-0591-3

5. Cambier L, de Couto G, Ibrahim A, Echavez AK, Valle J, Liu W, Kreke M, Smith RR, Marban L, Marban E (2017) Y RNA fragment in extracellular vesicles confers cardioprotection via modulation of IL-10 expression and secretion. EMBO Mol Med 9:337-352. https://doi.org/10.15252/emmm.201606924

6. Chakravarty T, Henry TD, Kittleson M, Lima J, Siegel RJ, Slipczuk L, Pogoda JM, Smith RR, Malliaras K, Marban L, Ascheim DD, Marban E, Makkar RR (2020) Allogeneic cardiospherederived cells for the treatment of heart failure with reduced ejection fraction: the Dilated cardiom Yopathy iNtervention with Allogeneic MyocardIally-regenerative Cells (DYNAMIC) trial. EuroIntervention 16:e293-e300. https://doi.org/10.4244/ EIJ-D-19-00035

7. Cheng K, Ibrahim A, Hensley MT, Shen D, Sun B, Middleton R, Liu W, Smith RR, Marban E (2014) Relative roles of CD90 and c-kit to the regenerative efficacy of cardiosphere-derived cells in humans and in a mouse model of myocardial infarction. $\mathrm{J}$ Am Heart Assoc 3:e001260. https://doi.org/10.1161/JAHA.114. 001260

8. Cheng K, Malliaras K, Li TS, Sun B, Houde C, Galang G, Smith J, Matsushita N, Marban E (2012) Magnetic enhancement of cell retention, engraftment, and functional benefit after intracoronary delivery of cardiac-derived stem cells in a rat model of ischemia/ reperfusion. Cell Transplant 21:1121-1135. https://doi.org/10. 3727/096368911X627381

9. Chimenti I, Smith RR, Li TS, Gerstenblith G, Messina E, Giacomello A, Marban E (2010) Relative roles of direct regeneration versus paracrine effects of human cardiosphere-derived cells transplanted into infarcted mice. Circ Res 106:971-980. https:// doi.org/10.1161/CIRCRESAHA.109.210682

10. Davis DR, Zhang Y, Smith RR, Cheng K, Terrovitis J, Malliaras K, Li TS, White A, Makkar R, Marban E (2009) Validation of the cardiosphere method to culture cardiac progenitor cells from myocardial tissue. PLoS ONE 4:e7195. https://doi.org/10.1371/ journal.pone.0007195

11. Gaetani R, Ledda M, Barile L, Chimenti I, De Carlo F, Forte E, Ionta V, Giuliani L, D’Emilia E, Frati G, Miraldi F, Pozzi D, Messina E, Grimaldi S, Giacomello A, Lisi A (2009) Differentiation of human adult cardiac stem cells exposed to extremely lowfrequency electromagnetic fields. Cardiovasc Res 82:411-420. https://doi.org/10.1093/cvr/cvp067

12. Gago-Lopez N, Awaji O, Zhang Y, Ko C, Nsair A, Liem D, Stempien-Otero A, MacLellan WR (2014) THY-1 receptor expression differentiates cardiosphere-derived cells with divergent cardiogenic differentiation potential. Stem Cell Rep 2:576-591. https://doi.org/10.1016/j.stemcr.2014.03.003

13. Gnecchi M, Zhang Z, Ni A, Dzau VJ (2008) Paracrine mechanisms in adult stem cell signaling and therapy. Circ Res 103:1204-1219. https://doi.org/10.1161/CIRCRESAHA.108. 176826

14. Ibrahim AG, Cheng K, Marban E (2014) Exosomes as critical agents of cardiac regeneration triggered by cell therapy. Stem Cell Rep 2:606-619. https://doi.org/10.1016/j.stemcr.2014.04. 006

15. Kogan P-S, Wirth F, Tomar A, Darr J, Teperino R, Lahm H, Dreßen M, Puluca N, Zhang Z, Neb I, Beck N, Luzius T, de la Osa Luis, de la Rosa Gärtner K, Hüls C, Zeidler R, Ramanujam D, Engelhardt S, Wenk C, Mononen M, Sahara M, Holdt L, Cleuziou J, Hörer J, Lange R, Krane M, Doppler S (2022) Uncovering the molecular identity of cardiosphere-derived cells (CDCs) by single cell RNA sequencing. Basic Res Cardiol. https://doi.org/10.1007/ s00395-022-00913-y

16. Li TS, Cheng K, Malliaras K, Matsushita N, Sun B, Marban L, Zhang Y, Marban E (2011) Expansion of human cardiac stem cells in physiological oxygen improves cell production efficiency and potency for myocardial repair. Cardiovasc Res 89:157-165. https://doi.org/10.1093/cvr/cvq251

17. Lian X, Hsiao C, Wilson G, Zhu K, Hazeltine LB, Azarin SM, Raval KK, Zhang J, Kamp TJ, Palecek SP (2012) Robust cardiomyocyte differentiation from human pluripotent stem cells via temporal modulation of canonical Wnt signaling. Proc Natl Acad Sci USA 109:E1848-1857. https://doi.org/10.1073/pnas.12002 50109

18. Makkar RR, Kereiakes DJ, Aguirre F, Kowalchuk G, Chakravarty T, Malliaras K, Francis GS, Povsic TJ, Schatz R, Traverse JH, Pogoda JM, Smith RR, Marban L, Ascheim DD, Ostovaneh MR, Lima JAC, DeMaria A, Marban E, Henry TD (2020) Intracoronary ALLogeneic heart STem cells to Achieve myocardial Regeneration (ALLSTAR): a randomized, placebo-controlled, doubleblinded trial. Eur Heart J 41:3451-3458. https://doi.org/10.1093/ eurheartj/ehaa541

19. Makkar RR, Smith RR, Cheng K, Malliaras K, Thomson LE, Berman D, Czer LS, Marban L, Mendizabal A, Johnston PV, Russell SD, Schuleri KH, Lardo AC, Gerstenblith G, Marban E (2012) Intracoronary cardiosphere-derived cells for heart regeneration after myocardial infarction (CADUCEUS): a prospective, randomised phase 1 trial. Lancet 379:895-904. https://doi.org/10. 1016/S0140-6736(12)60195-0

20. Malliaras K, Li TS, Luthringer D, Terrovitis J, Cheng K, Chakravarty T, Galang G, Zhang Y, Schoenhoff F, Van Eyk J, Marban L, Marban E (2012) Safety and efficacy of allogeneic cell therapy in infarcted rats transplanted with mismatched cardiosphere-derived cells. Circulation 125:100-112. https://doi.org/ 10.1161/CIRCULATIONAHA.111.042598

21. Malliaras K, Makkar RR, Smith RR, Cheng K, Wu E, Bonow RO, Marban L, Mendizabal A, Cingolani E, Johnston PV, Gerstenblith G, Schuleri KH, Lardo AC, Marban E (2014) Intracoronary cardiosphere-derived cells after myocardial infarction: evidence of therapeutic regeneration in the final 1-year results of the CADUCEUS trial (CArdiosphere-Derived aUtologous stem CElls to reverse ventricUlar dySfunction). J Am Coll Cardiol 63:110-122. https://doi.org/10.1016/j.jacc.2013.08.724

22. Malliaras K, Zhang Y, Seinfeld J, Galang G, Tseliou E, Cheng K, Sun B, Aminzadeh M, Marban E (2013) Cardiomyocyte proliferation and progenitor cell recruitment underlie therapeutic regeneration after myocardial infarction in the adult mouse heart. EMBO Mol Med 5:191-209. https://doi.org/10.1002/emmm.201201737

23. Marban E (2018) A mechanistic roadmap for the clinical application of cardiac cell therapies. Nat Biomed Eng 2:353-361. https:// doi.org/10.1038/s41551-018-0216-Z 
24. Marban E (2021) A phoenix rises from the ashes of cardiac cell therapy. Nat Rev Cardiol 18:743-744. https://doi.org/10.1038/ s41569-021-00625-1

25. McDonald CM, Marbán E, Hendrix S, Hogan N, Smith RR, Eagle M, Finkel RS, Tian C, Janas J, Harmelink MM, Varadhachary AS, Taylor MD, Hor KN, Mayer OH, Henricson EK, Furlong P, Ascheim DA, Rogy S, Williams P, Marbán L, the HOPE-2 Study Group (2022) Human Cardiosphere-derived Cells in Latestage Duchenne Muscular Dystrophy : a multicentre, randomised, double-blind, placebo-controlled, phase 2 trial. Lancet in press

26. Melsen JE, van Ostaijen-Ten Dam MM, Lankester AC, Schilham MW, van den Akker EB (2020) A comprehensive workflow for applying single-cell clustering and pseudotime analysis to flow cytometry data. J Immunol 205:864-871. https://doi.org/10.4049/ jimmunol.1901530

27. Mishra R, Vijayan K, Colletti EJ, Harrington DA, Matthiesen TS, Simpson D, Goh SK, Walker BL, Almeida-Porada G, Wang D, Backer CL, Dudley SC Jr, Wold LE, Kaushal S (2011) Characterization and functionality of cardiac progenitor cells in congenital heart patients. Circulation 123:364-373. https://doi.org/10.1161/ CIRCULATIONAHA.110.971622

28. Mononen MM, Leung CY, Xu J, Chien KR (2020) Trajectory mapping of human embryonic stem cell cardiogenesis reveals lineage branch points and an ISL1 progenitor-derived cardiac fibroblast lineage. Stem Cells 38:1267-1278. https://doi.org/10. 1002/stem.3236

29. Rogers RG, Fournier M, Sanchez L, Ibrahim AG, Aminzadeh MA, Lewis MI, Marban E (2019) Disease-modifying bioactivity of intravenous cardiosphere-derived cells and exosomes in $\mathrm{mdx}$ mice. JCI Insight. https://doi.org/10.1172/jci.insight.125754

30. Smith RR, Barile L, Cho HC, Leppo MK, Hare JM, Messina E, Giacomello A, Abraham MR, Marban E (2007) Regenerative potential of cardiosphere-derived cells expanded from percutaneous endomyocardial biopsy specimens. Circulation 115:896-908. https://doi.org/10.1161/CIRCULATIONAHA.106.655209

31. Takehara N, Tsutsumi Y, Tateishi K, Ogata T, Tanaka H, Ueyama T, Takahashi T, Takamatsu T, Fukushima M, Komeda M, Yamagishi M, Yaku H, Tabata Y, Matsubara H, Oh H (2008) Controlled delivery of basic fibroblast growth factor promotes human cardiosphere-derived cell engraftment to enhance cardiac repair for chronic myocardial infarction. J Am Coll Cardiol 52:1858-1865. https://doi.org/10.1016/j.jacc.2008.06.052

32. Tang YL, Zhu W, Cheng M, Chen L, Zhang J, Sun T, Kishore R, Phillips MI, Losordo DW, Qin G (2009) Hypoxic preconditioning enhances the benefit of cardiac progenitor cell therapy for treatment of myocardial infarction by inducing CXCR4 expression. Circ Res 104:1209-1216. https://doi.org/10.1161/CIRCRESAHA. 109.197723

33. Taylor M, Jefferies J, Byrne B, Lima J, Ambale-Venkatesh B, Ostovaneh MR, Makkar R, Goldstein B, Smith RR, Fudge J, Malliaras K, Fedor B, Rudy J, Pogoda JM, Marban L, Ascheim DD, Marban E, Victor RG (2019) Cardiac and skeletal muscle effects in the randomized HOPE-Duchenne trial. Neurology 92:e866e878. https://doi.org/10.1212/WNL.0000000000006950

34. Tseliou E, de Couto G, Terrovitis J, Sun B, Weixin L, Marban L, Marban E (2014) Angiogenesis, cardiomyocyte proliferation and anti-fibrotic effects underlie structural preservation post-infarction by intramyocardially-injected cardiospheres. PLoS One. 9:e88590

35. Tseliou E, Fouad J, Reich H, Slipczuk L, de Couto G, Aminzadeh M, Middleton R, Valle J, Weixin L, Marban E (2015) Fibroblasts rendered antifibrotic, antiapoptotic, and angiogenic by priming with cardiosphere-derived extracellular membrane vesicles. J Am Coll Cardiol 66:599-611. https://doi.org/10.1016/j.jacc.2015.05. 068

36. van Berlo JH, Kanisicak O, Maillet M, Vagnozzi RJ, Karch J, Lin SC, Middleton RC, Marban E, Molkentin JD (2014) c-kit+ cells minimally contribute cardiomyocytes to the heart. Nature 509:337-341. https://doi.org/10.1038/nature13309

37. Wang L, Yu P, Zhou B, Song J, Li Z, Zhang M, Guo G, Wang Y, Chen X, Han L, Hu S (2020) Single-cell reconstruction of the adult human heart during heart failure and recovery reveals the cellular landscape underlying cardiac function. Nat Cell Biol 22:108-119. https://doi.org/10.1038/s41556-019-0446-7

38. White AJ, Smith RR, Matsushita S, Chakravarty T, Czer LS, Burton K, Schwarz ER, Davis DR, Wang Q, Reinsmoen NL, Forrester JS, Marban E, Makkar R (2013) Intrinsic cardiac origin of human cardiosphere-derived cells. Eur Heart J 34:68-75. https://doi.org/ 10.1093/eurheartj/ehr172

39. Zakharova L, Mastroeni D, Mutlu N, Molina M, Goldman S, Diethrich E, Gaballa MA (2010) Transplantation of cardiac progenitor cell sheet onto infarcted heart promotes cardiogenesis and improves function. Cardiovasc Res 87:40-49. https://doi.org/10. 1093/cvr/cvq027

40. Zhang Y, Li TS, Lee ST, Wawrowsky KA, Cheng K, Galang G, Malliaras K, Abraham MR, Wang C, Marban E (2010) Dedifferentiation and proliferation of mammalian cardiomyocytes. PLoS ONE 5:e12559. https://doi.org/10.1371/journal.pone.0012559 